\title{
Por la democratización imposible. La revista Cuestionario y la tercera presidencia de Perón (1973-1974) ${ }^{1}$
}

\author{
For the impossible democratization. The magazine Cuestionario and the third \\ Presidency of Perón (1973-1974)
}

\author{
Marcelo Borrelli \\ marcebor@yahoo.com \\ CONICET / Universidad de Buenos Aires, \\ Argentina
}

Recepción: 02 Septiembre 2019

Aprobación: 05 Marzo 2020

Publicación: 01 Marzo 2021

Cita sugerida: Borrelli, M. (2021). Por la

democratización imposible. La revista Cuestionario y la tercera presidencia de Perón (1973-1974). Sociohistórica, 47, e121. https://doi.org/10.24215/18521606e121
Resumen: En este artículo se estudia la posición editorial de la revista Cuestionario ante el proceso político que desembocó en la tercera presidencia de Perón. En particular, se analiza su pensamiento en torno a temas y acontecimientos clave del momento: el conflicto interno en el peronismo, el crecimiento de la violencia política, el proyecto político de Perón en torno a la "unidad nacional", su rol como líder y el escenario abierto ante su desaparición física.

Bajo la dirección del periodista Rodolfo Terragno, el mensuario Cuestionario se lanzó al público en mayo de 1973 y su publicación se extendió hasta junio de 1976. Durante este tiempo se destacó por ofrecer un espacio para el debate de ideas, un pensamiento editorial con cierta pretensión de autonomía de los sectores políticos en pugna y una prédica de izquierda moderada que, en el contexto de 1973-1974, planteará la democratización de las prácticas políticas y la actualización doctrinaria del peronismo como herramientas fundamentales para resolver los dilemas de la hora.

Palabras clave: Revista Cuestionario, Perón, Peronismo, Terragno.

Abstract: This article studies the editorial position of the magazine Questionnaire in the face of the political process that led to Perón's third presidency. In particular, his thinking about key issues and events of the moment is analyzed: the internal conflict in Peronism, the growth of political violence, Perón's political project around "national unity", his role as leader and the open stage before his physical disappearance.

Under the direction of the journalist Rodolfo Terragno, the monthly Questionnaire was launched to the public in May 1973 and its publication will be extended until June 1976. During this time it was noted for offering a space for the debate of ideas, an editorial thought with a certain claim of autonomy of the political sectors in conflict and a moderate left preaching that, in the context of 1973-1974, will propose the democratization of political practices and the doctrinal updating of Peronism as fundamental tools to solve the dilemmas of the hour.

Keywords: Cuestionario magazine, Perón, Peronism, Terragno. 


\section{INTRODUCCIÓN}

Este artículo tiene como objetivo analizar la posición editorial de la revista Guestionario ante el proceso político que desembocó en la tercera presidencia de Perón (12 de octubre de 1973 al $1^{\circ}$ de julio de 1974), tomando como eje analítico algunas de las cuestiones clave enfatizadas por la misma revista, como el conflicto interno en el peronismo, el agravamiento de la violencia política, el proyecto político de Perón en torno a la "unidad nacional", su rol como líder y el escenario abierto ante su desaparición física.

El nacimiento de Cuestionario estuvo ligado al nuevo momento político que marcó el retorno del peronismo al poder en mayo de 1973 y la expectativa que abrió sobre las posibilidades de cambios más igualitarios en la sociedad argentina. Desde una perspectiva de izquierda nacional moderada, la revista dirigida por Rodolfo Terragno se destacó por su reflexión aguda sobre el proceso político abierto con el regreso peronista, que apeló a cierta pretensión de equidistancia de los grupos políticos en pugna para avanzar en un análisis mayormente desapasionado de la realidad nacional. Bajo esta orientación, su vida como medio se consolidó para extenderse hasta mediados de 1976, ya con la dictadura militar en el poder. Pese a forjar un lugar propio en el abanico de la prensa política de la época, no contamos desde las Ciencias Sociales con estudios específicos sobre sus posiciones editoriales, motivo por el cual este artículo pretende ser un primer acercamiento que habilite futuras indagaciones.

\section{Sobre Cuestionario}

En la Argentina, entre las décadas del sesenta y setenta, se desarrolló un intenso clima de discusión política en el marco del cual las revistas políticas de actualidad desempeñaron un rol protagónico (Carman, 2015). ${ }^{2}$ Medios como Primera Plana (1962-1973), Panorama (1963-1975/1976-1977), Confirmado (1965-1973/1976-1980), Extra (1965-1989), Redacción (1973-2003) o Carta Politica (1974-1975/1976-1980), entre los más destacables, conformaron un espacio de consumo para lectores exigentes, en busca de nuevas informaciones y, más aún, de análisis agudos y originales.

Dentro de ese abanico de medios hizo su aparición Cuestionario, que publicó su primer número en mayo de 1973. Con una periodicidad mensual -aparecía el primer jueves del mes-, estaba destinada a un público de clase media politizada y, en particular, se dirigía a un sector de la izquierda intelectual moderada con impronta nacionalista. Su impulsor y director fue el abogado y en ese entonces periodista Rodolfo Terragno, ${ }^{3}$ quien según su testimonio lanzó la revista ante la certeza -por las presiones que había recibido trabajando en otros medios- de que la única forma de hacer "periodismo independiente" era tener un medio propio. ${ }^{4}$ Para ese entonces Terragno no tenía una militancia política-partidaria pero se identificaba con el desarrollismo frondicista, ${ }^{5}$ había expresado posiciones contrarias a la dictadura de la "Revolución Argentina" (1966-1973) y creía en una sociedad más igualitaria donde se verificara una distribución del ingreso más equitativa, pero no apoyaba las ideas revolucionarias ni la lucha armada como metodología. ${ }^{6}$

La revista fue financiada inicialmente por la editorial Peña Lillo ${ }^{7}$ y se publicó hasta el número 38 de junio de 1976, poco después de iniciada la dictadura militar, cuando en la nueva coyuntura represiva Terragno se vio obligado a cerrar la revista y exiliarse en Venezuela. Además del interés central en la política argentina, se destacaron sus notas culturales y sobre temas de "vanguardia" (por ejemplo, el divorcio), el interés por auscultar la realidad de otros medios de comunicación, su preocupación por la libertad de prensa, el análisis del poder económico en América latina y Argentina -destacándose el análisis de las grandes empresas- y la política internacional, entre otros.

En un inicio se publicó en formato tabloide $(20 \times 40 \mathrm{~cm})$, impreso en blanco y negro en papel de diario (menos su tapa y contratapa, que eran a color y con papel tipo revista). A partir del número 25 (en mayo de 1975) su formato pasó al de revista, de 20 x $28 \mathrm{~cm}$, en blanco y negro, pero con papel de mayor calidad. 
Sus primeras ediciones fueron de 28 páginas, que se extendieron a las 36 en algunos números. Hasta octubre de 1974 no hubo división por secciones. Con el cambio de formato a mediados de 1975, que daba cuenta de su consolidación como medio periodístico, sus páginas aumentaron considerablemente hasta las 68 . Su tirada en el periodo de estudio de este artículo, según la información de la misma revista, fue de entre 22 y 25 mil ejemplares. En relación con sus avisadores, en una primera instancia la mayoría fueron radios, diarios y editoriales vinculados al ámbito cultural e intelectual del público de izquierda moderada al que se dirigía, y luego incorporó otros avisadores privados y públicos. Desde su primer número hasta el último en 1976 Terragno firmó las contratapas, que se destacaron por un análisis sutil de la coyuntura política. Algunos de los colaboradores más destacados de la redacción fueron Lorenzo Amengual, Jorge Gietz, Enrique Koenig, Anibal Walfisoh, Andres Cisneros, Aída Bortnik, Jack Anderson, Salvador Ferla, Osvaldo Ferrero, Hugo Pérez, Zelmar Michelini, Francisco Ferrara, Fernando Más, Pedro Cabral, Carlos Ulanovsky, Carlos María Gutiérrez, Rómulo Rinaldi, Mario Marrero Díaz, Emilio Corbiere, Gregorio Selser y Eugenio Rey.

Desde su número inicial, Cuestionario hizo de la reivindicación de sus principios ideológicos, de la "honestidad" hacia el lector y de la transparencia intelectual un eje de su discurso editorial y de su identidad enunciativa. Al respecto, en su primera edición de mayo de 1973, en lo que Ulanovsky (2005, p. 51) consideró como un "ejercicio de transparencia insólito para aquel tiempo", ofrecía respuestas explícitas a tres interrogantes que la prensa tradicional suele solapar; en sus palabras: "Qué hay detrás de CUESTIONARIO", "Cuál es la posición política de CUESTIONARIO” y "Cómo se financia CUESTIONARIO". ${ }^{8}$ En relación con el primero de ellos, aseguraba que no había “intereses ocultos” y que la revista era impulsada por personas de trayectoria pública como Terragno y Arturo Peña Lillo. En relación con su postura política, los editores declaraban que estaban dispuestos a "apoyar al gobierno popular" -en referencia al gobierno de Cámpora que se iniciaría el 25 de mayo de 1973-, teniendo en cuenta que era el "pueblo" el que había infligido una derrota al gobierno militar, pero aclaraba que ese apoyo no significaba la "adhesión sin condiciones", por lo que se reservaba "el más amplio derecho a crítica". 9 Sobre su financiamiento, manifestaba que sería a través de la venta, las suscripciones y los avisos, mientras que la publicidad no comprometería la "autonomía de los editores", y buscaba diferenciarse de sus colegas al declarar que la política editorial no "estaría condicionada a compromisos comerciales", 10 a diferencia de aquella prensa que bajo una estela informativa difundía "publicidad encubierta" o de quienes eran "voceros de las empresas ante el poder público". ${ }^{11}$ Para Cuestionario, en cambio, la "honestidad" era "un buen negocio" y buscaba ejercer un "periodismo independiente" que criticara "libremente" y se acercara a la "gente", lejos del periodismo comercial subsidiado o el no comercial de lógica facciosa.

Este posicionamiento ético y profesional se complementaba con una reivindicación del pluralismo y el debate de ideas -que se concretó en la difusión de puntos de vista ideológicamente antagónicos-, ${ }^{12}$ y el análisis agudo de la coyuntura política, que se distinguía en un clima de ideas y una cultura política en los que el faccionalismo, la radicalización y la lógica amigo-enemigo marcaban las grandes tendencias del escenario político nacional. ${ }^{13}$ Dentro de esa propuesta, Cuestionario intentó recuperar y potenciar el clima antiautoritario del epílogo de la "Revolución Argentina" y el marco esperanzador para las propuestas reformistas desde la izquierda que generaba el nuevo gobierno peronista.

Un último aspecto destacable de la revista fue su interés por promover el intercambio con sus lectores, canalizado a través de la sección "Cartas", en la quefueron publicados con frecuencia comentarios valorativos del contenido editorial, tanto positivos como negativos, y se dio lugar al debate intelectual o político sobre diversos temas. ${ }^{14}$ En este campo, se observa desde Cuestionario la construcción de un lector activo, participativo y exigente, en el marco de un contrato de lectura ${ }^{15}$ entre revista y lectores basado en el compromiso mutuo, la aceptación de la crítica aguda y constructiva, la honestidad intelectual y la transparencia. 


\section{EL ENFOQUe METODOLÓGico}

Este artículo se inserta dentro de un proyecto de investigación más amplio que analiza diversas revistas de orientación política -en tanto la política en general, y la política nacional en particular, fueron el objeto privilegiado de su agenda temática- durante los gobiernos peronistas de 1973 a $1976 .{ }^{16}$ Se trata de emprendimientos periodísticos que le otorgaron un particular énfasis al género de opinión y al sesgo reflexivo -a diferencia de las publicaciones diarias, más concentradas en el aspecto informativo-, lo cual las convierte en fuente de sumo valor para dar cuenta de las corrientes de opinión político-ideológica en la coyuntura y de las interpretaciones sobre la realidad nacional que pudieron haber legitimado o deslegitimado a los actores políticos.

El trabajo se inscribe dentro del campo de estudios sobre las líneas editoriales de la prensa argentina y entiende el editorial como el espacio institucional en el que se resume el posicionamiento del medio y se sistematiza su orientación política e ideológica (Borrat, 1989; Sidicaro, 1993). En Cuestionario esto se expresó en las contratapas firmadas por su director, como también en las tapas y las notas de actualidad política que contenían una toma de posición explícita. Si bien, entonces, nuestro interés se recortará sobre estas secciones en particular, como todo medio de este tipo Cuestionario fue un emprendimiento cuya riqueza y heterogeneidad excede el recorte aquí propuesto, por lo cual merece futuras indagaciones.

La metodología de estudio apeló a una perspectiva de análisis cualitativo de fuentes y apuntó a exponer y comprender críticamente la posición editorial de la revista. Se han utilizado dos formas básicas de uso de los datos: el modo ilustrativo, que utiliza las citas como ejemplos de una descripción o conclusión del investigador, y el modo analítico, que se propone analizar las construcciones que los sujetos o actores realizan a partir de la identificación de las categorías que organizan su relato (Kornblit, 2004, p.11).

\section{EL RETORNO DEL PERONISMO AL PODER EN 1973}

El fin del gobierno militar de la "Revolución Argentina" estuvo marcado por la movilización popular, el reverdecer de las demandas sociales, el ascenso del sindicalismo combativo, la lucha armada de las organizaciones político-armadas de izquierda (peronistas y no peronistas) contra el autoritarismo militar y el fracaso del Estado militar para conciliar los conflictos sociales. En este marco, en 1973 Perón -exiliado desde el golpe militar que había derrocado a su gobierno en septiembre de 1955- parecía ser el único actor político con capacidad para armonizar el conflicto social y morigerar las reivindicaciones extremas y la lucha armada (que él mismo había atizado desde el exilio como forma de erosionar a la dictadura). Así lo entendieron los militares y las elites dominantes argentinas, conscientes de que no había más margen político para mantener la proscripción electoral del peronismo. Aunque la dictadura logró impedir que Perón participara de las elecciones del 11 de marzo de 1973 con un obstáculo legal, éste eligió a su delegado Héctor Cámpora como su representante para la contienda electoral, una figura considerada "moderada" por los militares frente a otras opciones provenientes del ala más radical del peronismo. De todas formas, Cámpora contó con el apoyo del peronismo de izquierda, que tuvo un rol primordial en la campaña electoral que desembocaría en el triunfo de la fórmula Cámpora- Solano Lima como candidatos del FREJULI ${ }^{17}$ (Bonasso, 1997). Cámpora asumió la presidencia de la nación el 25 de mayo, pero debió renunciar el 13 de julio de ese año bajo el asedio de sus enemigos internos y la desconfianza del mismo Perón, dispuesto a tomar personalmente las riendas del gobierno y frenar el avance de la juventud revolucionaria para equilibrar las fuerzas dentro de su heterogéneo movimiento (Csipka, 2013). Es que con la llegada al poder del peronismo se abrió con toda contundencia la disputa interna entre los sectores de la Tendencia Revolucionaria ${ }^{18}$ que proponían el “socialismo nacional” -más allá de cuál era realmente su contenido programático, que no estaba claro- y la derecha, que propugnaba la "patria peronista" y estaba representada por la dirigencia sindical peronista, los 
peronistas "históricos", diversos dirigentes y organizaciones vinculados al nacionalismo de derecha y un grupo de reciente incorporación en torno al secretario privado de Perón y ministro de Bienestar Social, José López Rega (De Riz, 1986, p. 94; Maceyra, 1983, pp. 41-42). ${ }^{19}$

Estas contradicciones se hicieron trágicamente visibles para la opinión pública el 20 de junio de 1973, fecha del regreso definitivo del líder al país, cuando la derecha del peronismo causó una verdadera masacre en los bosques de Ezeiza al impedir que los simpatizantes de la Tendencia y Montoneros ocuparan posiciones cercanas al palco central donde Perón iba a dar un discurso ante la multitud (Verbitsky, 1998). Las declaraciones de Perón por cadena de radio y televisión el día siguiente a esa jornada aciaga, en las que, entre otras afirmaciones, advirtió contra los que intentaban "infiltrarse" en el movimiento (Perón, 1974a, pp. 51-52), dejaban en claro que el líder estaba alejándose de sus posiciones de antaño en defensa de la juventud "maravillosa" y las "formaciones especiales", y ahora, con la certeza de manejar los hilos del Estado nuevamente, pretendía disciplinar a los sectores revolucionarios de su movimiento.

Este desplazamiento se dio en el marco de un acercamiento de Perón hacia los partidos políticos de la oposición de raíz "nacional y popular", fundamentalmente con la Unión Cívica Radical liderada por Ricardo Balbín, a través de un discurso que fundaba el nuevo momento en la "unión nacional" y la búsqueda de mecanismos institucionales para la preservación del sistema (Godio, 1986; de Riz, 1986; Landi, 1978). Como indicó Landi (1978), era un Perón "ambivalente”, ya no solamente preocupado por ejercer su liderazgo dentro del peronismo, sino también con aspiraciones a convertirse "en el agente central de reconstrucción de un orden político nacional"; un Perón "desperonizado", que intentó ubicar su figura "por encima de las disputas políticas" (p.25). Aunque, junto con ese movimiento estratégico, debe advertirse, como señala Tcach (2002), que lo que nació con la "doctrina Ezeiza" era un "doble discurso" en el que, junto a las apelaciones a la paz, la democracia y la unión nacional se convalidaba la impunidad para quienes desde el Estado -o desde las facciones amigas- se propusiesen eliminar al adversario político (pp. 74-76) (y, en efecto, desde los sucesos de Ezeiza la persecución contra la izquierda recrudeció vertiginosamente).

En este marco, los principales temas que hegemonizaron la tercera presidencia de Perón fueron el conflicto interno en el movimiento peronista, el incremento de la violencia política, el enfrentamiento entre Perón y la Tendencia Revolucionaria y los problemas económicos vinculados al Pacto social ${ }^{20}$ (Garategaray, 2009, p. 15).

\section{Cuestionario y EL REtorno PERONista: EL “TRIUNFO DE LA REALIDAD”}

Para el director de Cuestionario, el retorno del peronismo al poder luego de las elecciones del 11 de marzo había sido un "triunfo de la realidad" frente a la intención de sus opositores de negar su existencia en la política nacional. ${ }^{21}$ Pero la clave del momento en mayo de 1973 era que Perón comprendiera lo que sus bases demandaban, que no era meramente replicar el modelo del primer peronismo sino una "política de transformación" que, sin "comportarse como el orangután en el bazar", satisficiera a una población ansiosa de "cambios sustanciales". ${ }^{22}$ Esa demanda de la revista se enlazaba, desde ya, con el nuevo clima social postdictadura, con el peso que la "juventud revolucionaria" había tenido en la campaña electoral y con cierta percepción de que la transformación social propiciada por los sectores políticos movilizados era "inevitable", aunque hubiera que discutir los plazos de su ejecución. De allí que la revista demostrara una particular preocupación por auscultar cómo se verificarían esos cambios, con los que en términos generales acordaba, y que para el ala revolucionaria del peronismo suponían la implantación del "socialismo nacional”. Pero como prontamente Cuestionario lo puso de relieve, los obstáculos para la implementación de este proyecto político eran ingentes; en principio, cuál sería el contenido programático de ese "socialismo nacional", ${ }^{23}$ y -el que marcaría una de las claves de esta etapa- la resistencia de los sectores no revolucionarios del peronismo -y finalmente del mismo Perón- a darle un curso radicalizado de izquierda al nuevo gobierno. Para la revista, la 
dificultad de esta implementación ya había quedado expuesta muy tempranamente con la elección del equipo económico en manos del nuevo ministro del área José Ber Gelbard, el líder de la Confederación General Empresaria (CGE) que indudablemente no ofrecía para Cuestionario, ni para la Tendencia, "garantías revolucionarias". 24

Frente a los sucesos de Ezeiza, y la posterior declaración de Perón que fue comprendida como un gesto de apoyo a la derecha de su movimiento, Terragno procuró ensayar una interpretación de "alta política", al afirmar que no debía verse allí una "definición ideológica” del líder sino más bien la expresión de su "capacidad estratégica", ya que para evitar que el peronismo se "anarquice” debía detener a los "recién llegados" y recostarse sobre los que, como mérito más destacable o casi único, habían respetado la verticalidad. Así, con un peronismo controlado podría orientarse hacia metas más audaces que las "veinte verdades" peronistas afines a su sector ortodoxo -que había festejado el discurso posterior a Ezeiza-, y satisfacer también el anhelo de los sectores renovadores. ${ }^{25}$

Ante la forzada renuncia de Cámpora el 13 de julio de 1973, Terragno fue contundente para analizar el nuevo escenario que se abría. Sin eufemismos, aseguraba: "Cámpora fue derrocado. Su renuncia (...) es la formalización de un golpe de Estado", al entender que ese "golpe" tenía el signo ideológico de la "derecha peronista", que no avalaba la participación "minoritaria" que Cámpora -a quien la revista no reconocía como un "hombre de izquierda" - les había otorgado a los grupos revolucionarios. ${ }^{26}$ La clave de este nuevo momento era la instalación de Perón en el poder y la lucha entre la izquierda y la derecha del peronismo, que consideraba una "velada guerra civil", un enfrentamiento que, en estilo predictivo, ${ }^{27}$ advertía que no sería "breve ni incruento". E introducía en su análisis una variable que sería retomada meses después y que estaba, sottovoce, en la preocupación de todos los actores políticos: Perón, a los 77 años, no estaba lejos de su muerte o de su debilitamiento intelectual, y por lo tanto el peronismo necesitaba una "mayor precisión a su doctrina”. Era Perón el único que podía contribuir a esa clarificación -al designar a qué sectores sociales pretendía representar el peronismo- e institucionalizarse, como él mismo lo recomendaba, para evitar "que la lealtad a un hombre (...) siga siendo el principal mérito en el movimiento” y que lo que contara, en cambio, fuera la "lealtad a las ideas". ${ }^{28}$

Luego de la renuncia de Cámpora asumió la presidencia Raúl Lastiri, presidente de la Cámara de Diputados y yerno de López Rega, en una evidente maniobra prohijada por el cada vez más poderoso ministro de Bienestar Social y secretario privado de Perón. ${ }^{29}$ La puja de poder dentro del peronismo se trasladó prontamente a la definición de la candidatura a vicepresidente para las nuevas elecciones, que se llevarían adelante el 23 de septiembre y lo tendrían a Juan Perón como candidato presidencial. Luego de descartarse la posibilidad de una candidatura de "unión nacional” entre Perón y Balbín, el Congreso Nacional Justicialista consagró la candidatura "Perón-Perón” (por su esposa María Estela "Isabel” Martínez de Perón), que luego fue aceptada por el matrimonio. Era una definición que marcaba los nuevos tiempos por venir, ya que la juventud observaba a Isabel con suma desconfianza, en tanto no tenía una trayectoria política y estaba ligada a los sectores más reaccionarios del peronismo, ${ }^{30}$ además del encumbramiento que suponía para López Rega, quien para la Tendencia ya se encontraba en las filas enemigas. ${ }^{31}$

Cuestionario supo expresar con ironía ese rechazo de la juventud hacia la candidata, al presentar un juego de palabras entre el titular "La juventud votará a Perón" y la volanta "Pese a Isabel Martínez". ${ }^{2}$ Aunque también interpretó que había cierta "madurez" en los jóvenes peronistas en haber entendido que se trataba sólo de una "batalla perdida" dentro de la "guerra ideológica interna", y que por lo tanto no iban a salirse de ese movimiento de masas, ${ }^{33}$ que les permitía estar del lado de la clase trabajadora y así asegurar, para Terragno, "las posibilidades prácticas de un proyecto revolucionario". ${ }^{34}$ Por eso, pese a los que veían a la juventud "derrotada", en realidad no observaban que este sector estaba creando "pacientemente, las condiciones de su triunfo". 35 


\section{La tercera presidencia de Perón: “Y si se muere Perón?”}

El 23 de septiembre de 1973 la fórmula Perón-Perón triunfó con un abrumador 61,85\% de los sufragios(7.359.139 votos), dejando en un holgado segundo puesto al radicalismo con el 24,42\% de la fórmula Balbín-Fernando de la Rúa (Graham-Yooll, 2006, p. 282). Dos días después la interna peronista tomaba toda la atención pública ante el asesinato del líder de la CGT, José Ignacio Rucci, a manos de Montoneros (no reivindicado en ese momento por la organización). ${ }^{36}$ La complejidad política del momento era recuperada en la tapa de octubre de Cuestionario, que con un tinte sensacionalista titulaba en letra catástrofe "¿Qué va a pasar?", a lo que le seguía otra serie de interrogantes que culminaban con el inquietante "iY si se muere Perón?" (Figura 1). En la nota de tapa, la revista calificaba como "sensato" que Perón hubiera sido elegido presidente, luego de la proscripción que había llevado al país casi al "abismo”, pero de todas maneras describía que había cierta "angustia" e "impaciencia” ante el momento político, por eso se preguntaba: “Qué va a pasar ahora? ¿Cómo saldremos de esta situación? ¿Qué es lo que hará Perón?”. Para la revista, la coyuntura era por demás delicada: la guerrilla subsistía, el país estaba rodeado por dictaduras afines a Estados Unidos -con el reciente golpe en Chile que demostraba la "inviabilidad" de una revolución pacífica-, la economía exhibía un "considerable deterioro" y la salud del presidente era un tema de preocupación. ${ }^{37}$

Sobre los interrogantes planteados en la portada, destacaremos los más relevantes. Con respecto a si seguiría la violencia, su contestación era afirmativa porque la violencia "engendraba violencia", porque las causas que habían generado la acción guerrillera no desaparecerían tan rápido y porque el peronismo, a diferencia de la guerrilla que quería la "patria socialista”, parecía querer avanzar lentamente. En particular, llamaba la atención sobre el hecho de que en el peronismo parecía "estar gestándose una acción organizada de contrainsurgencia" a partir de haberse conocido a inicios de octubre la "orden reservada" del Consejo Superior Justicialista, que en efecto fue una respuesta ante el asesinato de Rucci y que daría inicio formal a la "depuración ideológica" contra la izquierda peronista. ${ }^{38}$ Pese a esta preocupación, la interpretación de esta política represiva y persecutoria era aún bastante contemplativa por parte de Cuestionario, que la entendía más como otro de los juegos tácticos de Perón orientados a equilibrar los conflictos internos. 
FIGURA 1

Cuestionario realiza la pregunta tabú: “¿Y si se muere Perón?” (octubre de 1973)

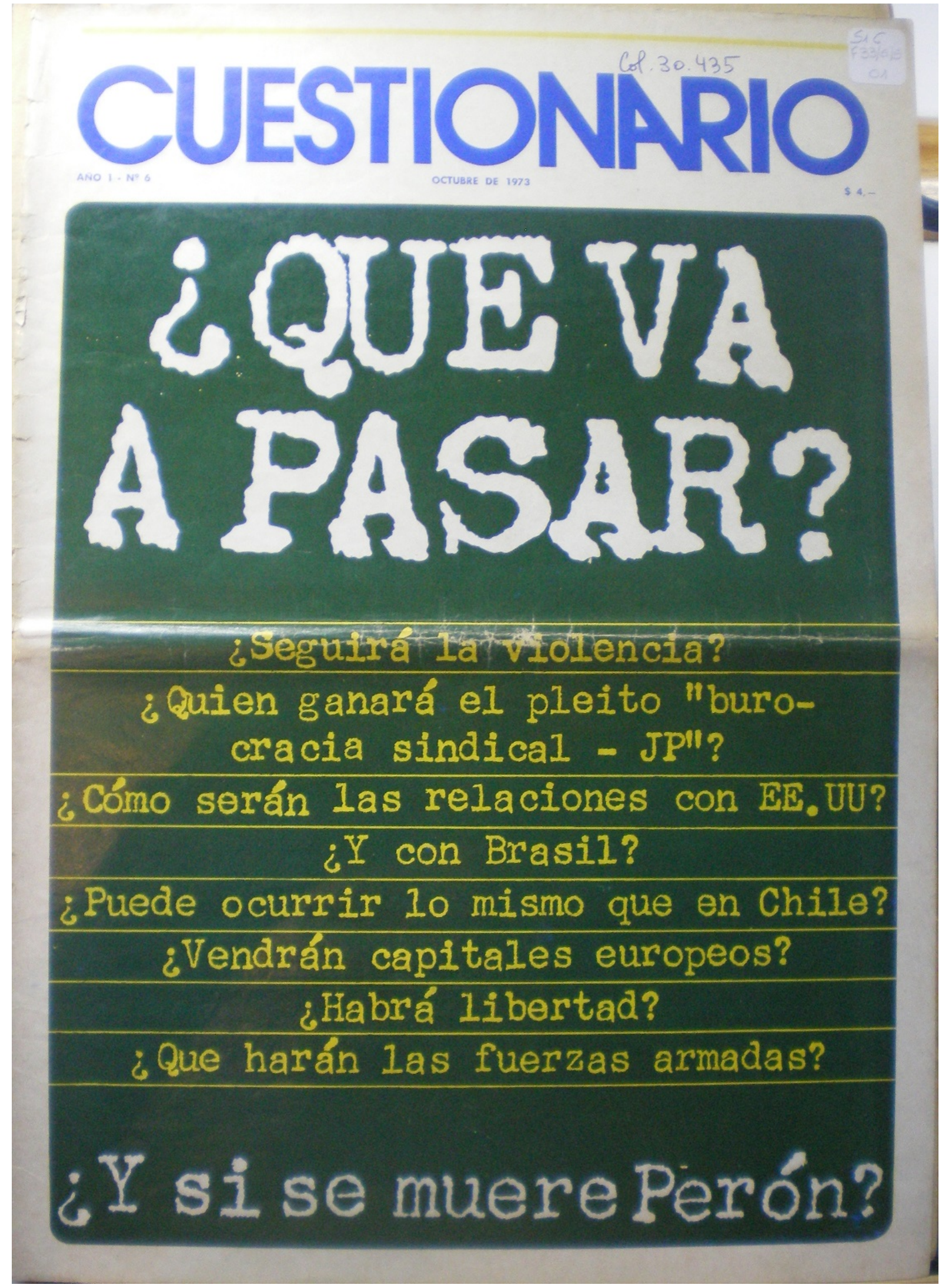


Sobre quién ganaría la disputa entre la "burocracia sindical” y la JP, entendía que, a corto plazo, sería el sindicalismo peronista, más aún luego de conocida la "orden reservada" y, agregamos, el reencuentro público entre Perón y la dirigencia sindical a inicios de octubre de 1973. ${ }^{39}$ Pero, a largo plazo, las exigencias de las bases peronistas terminarían llevando a una política más acorde con la juventud, de fuerte redistribución de ingresos o, directamente, de socialización de la propiedad. Mencionaba, incluso, que los sectores juveniles del peronismo solían citar una frase de Perón que afirmaba que a la juventud le tocaría el turno dentro de "tres años", por lo cual Cuestionario entendía que para 1976 el peronismo tendría que haber "girado" hacia la izquierda. Era un tipo de interpretación que ya había esbozado Terragno en su editorial "El triunfo de la juventud" de mayo de 1973 y que contenía cierta mirada "evolucionista" sobre la historia, por la cual ese giro que estaba demandando la juventud, y era resistido dentro del propio peronismo, formaba parte de cierta consecuencia "inevitable" de la evolución de la política y la historia. Por otra parte, esta lectura no parecía tener en cuenta hasta qué punto la táctica de Perón de restar poder y perseguir a la izquierda de su movimiento podría agravar el enfrentamiento entre este sector y el líder, con el consecuente perjuicio para la legitimidad del discurso revolucionario dentro del peronismo.

Sobre si podía ocurrir un golpe como en Chile, taxativamente se contestaba que no, principalmente porque Perón contaba con mucho más poder que Allende y tampoco se planteaba una "transformación de la Argentina al socialismo" como había intentado el recientemente fallecido y derrocado expresidente chileno. En este aspecto, sobre "qué harían" las Fuerzas Armadas en la coyuntura, sostenía que "por ahora, nada", aunque dejaba abierta la posibilidad de que en el futuro, si crecían los problemas, habría "grupos" que irían en su busca.

La pregunta nodal de esta serie de interrogantes era “¿Y si se muere Perón?”. Para Cuestionario, desde ya que su eventual desaparición física "agudizaría los conflictos internos del peronismo" y, según las circunstancias, "hasta podría devolver la iniciativa a las Fuerzas Armadas", con el elemento perturbador adicional de que la sucesión quedaría en manos de Isabel, que no era un factor aglutinante de fuerzas. Sin embargo, la crisis "ya existía" y con Perón solo no bastaba. A los que temían el caos, les recordaba lo ocurrido en Ezeiza, lo sucedido con Rucci o la violencia política cotidiana, lo cual estaba ocurriendo en vida de Perón. Había que comprender que un conductor político era siempre "un representante" y que, en definitiva, una fuerza que llegaba a reunir más del 60 por ciento de la población "no depende del ritmo cardíaco de un hombre de 78 años”. La cuestión principal para el país seguía siendo las disyuntivas entre liberación o dependencia y entre socialismo o explotación(de los trabajadores), y si en esa encrucijada el peronismo sería apto para conseguir la liberación y el socialismo. ${ }^{40}$

\section{La interna Peronista Y EL ROL De Perón: "Democratización” y "actualización DOCTRINARIA"}

Luego de la asunción de Perón en su tercera presidencia, la disputa interna en el peronismo y el futuro nacional ante su eventual desaparición física fueron parte de las preocupaciones centrales de Cuestionario. En noviembre de 1973 Terragno dedicó la contratapa a reflexionar sobre el "pleito peronista" que estaba hegemonizando todo el escenario político nacional. ${ }^{41}$ El director ensayaba una lectura histórica al recordar que en su surgimiento en la década del cuarenta el peronismo había elaborado una "doctrina" cuyo principio rector había sido el "nacionalismo populista", con acento en la soberanía política y económica y una serie de reivindicaciones sociales. En la coyuntura de 1973 el peronismo necesitaba ofrecer nuevas respuestas frente a una nueva realidad, y éstas aún no estaban preparadas y eran el objeto de las disputas internas. Los jóvenes querían darle un "nuevo contenido", mientras que "los antiguos peronistas" -y lo que indicaba como la "infiltración de derecha"- querían impedir esa adecuación doctrinaria (con lo cual, advertía, terminaría afectando ese principio rector, ya que un peronismo sin cambios no sería "ni nacionalista ni popular"). Frente 
a este sector, también describía a quienes proponían una "radicalización del peronismo" que, desde su punto de vista, también desvirtuaría ese "principio rector". Para el director, las respuestas que el "nacionalismo populista" debía dar a la situación argentina de 1973 debían tener en cuenta que se necesitaba "democratizar" el poder político, el poder económico y el poder sindical para canalizar la aspiración mayoritaria y construir un régimen "verdaderamente popular". ${ }^{42}$ Esa visión programática era refrendada por el director en marzo de 1974 al descartar como "falsas alternativas" los "extremos" del "conformismo", de quienes dejaban todo en manos del líder, y de los “exaltados”, para quienes la solución sólo saldría “de la boca de los fusiles”. En el medio había una ancha franja para desarrollar un "proyecto" de "gobierno popular", que era el de la "independencia económica" -principalmente del "imperialismo estadounidense"-, la "redistribución de ingresos" a favor de la clase media y la clase trabajadora, la participación de los trabajadores en la "gestión empresaria", la democratización de "todos los organismos de representación, como los partidos y los sindicatos" y la eliminación de los "métodos represivos". ${ }^{3}$

Esta apuesta programática de Cuestionario permite una reflexión sobre su posición enunciativa. Aunque ubicada desde fuera del colectivo peronista, pero con explícita simpatía por su contenido "nacional y popular", Cuestionario objetaba las posiciones radicalizadas hacia derecha e izquierda y reforzaba su adhesión a las reivindicaciones de una izquierda más moderada, que no apelaba a la lucha armada para la toma del poder, y que entendía que había que avanzar hacia reformas, profundas pero sólo reformas del sistema capitalista. También esas reformas debían incorporarse en la manera de hacer y organizar la política; por ello apelaba al concepto de "democratización", un término que indudablemente no estaba inserto en la práctica ni en la cultura política de la coyuntura, teñida de la lógica facciosa, el autoritarismo, la cultura de amigo-enemigo y la violencia como forma de dirimir los conflictos. Si bien, entonces, se ubicaba desde un lugar ético difícil de refutar en esos términos, el problema -enunciativo y político- de estas posiciones es hasta qué punto había espacio en la política argentina de 1973/1974 para hacer efectivas posiciones reformistas y "democratizadoras" frente al proceso de radicalización política que vivía la política argentina $\mathrm{y}$, particularmente, el peronismo.

La pregunta que se hacía Cuestionario en octubre sobre el eventual fallecimiento de Perón, incluso antes de asumir su tercera presidencia, era retomada con todo su peso por Terragno en su contratapa de diciembre titulada, ya en tono afirmativo: "Cuando Perón no esté". ${ }^{44}$ Consciente de que estaba tocando un tema "tabú”, ${ }^{45}$ marcaba la siguiente paradoja: "Si antes se simulaba que Perón no existía, ahora se simula que Perón es inmortal. Hay un pudor sacramental que impide considerar públicamente la eventualidad de que Perón muera antes de terminar su mandato". Por eso, había que hacer frente al tema y pensar ese futuro sin Perón. En principio, intentaba marcar el fino juego político que se estaba dando con esta hipótesis que recorría en sordina el escenario político nacional y alertaba que era "peligroso" que los peronistas le estuvieran dejando la tarea de la "actualización doctrinaria" a Perón, cuando se trataba de un proceso que "suponía tiempo" y Perón había cumplido recientemente 78 años. De allí que advirtiera que ese excesivo personalismo era funcional a los "sectores tradicionalmente antiperonistas", ya que "sólo la deificación de Perón servirá para contener el proceso de transformación revolucionaria del movimiento justicialista”. Además, el liberalismo sostenía que Perón era "insustituible", lo que dejaba abierta la posibilidad de que en el futuro se justificara la toma del poder cuando el líder desapareciera físicamente. Es decir, para el director, peronistas y antiperonistas estaban consolidando la idea de que el futuro de Argentina dependía de la "vida de Perón” y que una vez fallecido éste el país estaría perdido. De esa manera se estaba asistiendo a una "profecía autocumplida”, en tanto, al creer lo que podría ser una hipótesis, que luego de la muerte de Perón devendría el "caos", se estaban demorando ciertas decisiones y por ese motivo, finalmente tras su muerte, la profecía del caos se cumpliría. Lo que Terragno demandaba era que el peronismo realizara con urgencia esa "actualización doctrinaria" sobre la base de un "amplio y leal debate ideológico, capaz de culminar en la elaboración de un proyecto revolucionario, explícito y preciso", y no dejarlo para el momento "menos feliz", o sea, cuando la ausencia física del líder 
se concretara. ${ }^{46}$ Sin duda, a la luz de los hechos posteriores, se destacan el estilo predictivo y la capacidad premonitoria del director, pero paralelamente su planteo de "actualización” se volvía por demás abstracto frente a la realidad de proyectos políticos internos que aparecían como absolutamente irreconciliables.

Desde ya que Cuestionario y su director eran conscientes de estos obstáculos. Así lo explicitaron al analizar uno de los objetivos que se le atribuían a Perón en su tercera presidencia: el de diseñar "un nuevo sistema de organización política" que, bajo la impronta de la "unión nacional”, permitiera superar los conflictos políticos y consolidar una organización institucional que no dependiera de una sola persona. Terragno mencionaba una eventual reforma constitucional como forma de asegurar esos cambios, ${ }^{47}$ en tanto se institucionalizaría un sistema de participación pluripartidario en el Poder Ejecutivo y de las corporaciones sindical y empresaria en la gestión estatal. ${ }^{48}$ Con este sistema, la ausencia de Perón no sería un "supuesto tan trágico", ya que existiría una estructura institucional donde los principales actores sociales estarían representados. Pero la revista advertía con claridad que el problema radicaba en el mismo peronismo: en él se enfrentaban dos concepciones ideológicas "no negociables"; no podría haber pactos porque no había "intereses concurrentes", como sí tenían Perón, Balbín, los partidos y los dirigentes empresariales y gremiales, quienes querían salvar un sistema político del que todos participaban. Y si Perón lograba consolidar ese sistema institucional, estaría favoreciendo entonces a uno de esos sectores en disputa: el de los "dirigentes sindicales y el Consejo Superior" (porque este esquema de tinte claramente conservador del statu quo se daba de bruces con el planteo revolucionario de la Tendencia).

\section{La Juventud Peronista: "Entre la espada y la PARED"}

El año 1974 se inició con acontecimientos políticos que tendrían importantes repercusiones a corto plazo. En un clima de exacerbación de la violencia política cotidiana, el 19 de enero el Ejército Revolucionario del Pueblo (ERP) -brazo armado del trotskista Partido Revolucionario de los Trabajadores- atacó la guarnición militar de Azul en la provincia de Buenos Aires, en una acción de graves repercusiones que endureció las tendencias represivas del gobierno hacia la izquierda en general y hacia el peronismo revolucionario en particular. ${ }^{49} \mathrm{El}$ ataque ocurrió pocos días antes de que la Cámara de Diputados discutiera una reforma al Código Penal que reforzaba la tendencia represiva contra las organizaciones guerrilleras y el sindicalismo combativo (Godio, 1986, pp. 167-168). El proceso de discusión sobre esta reforma en el peronismo, sancionada finalmente el 25 de enero, enfrentó aún más a la Tendencia con Perón y los ocho diputados del FREJULI pertenecientes a la JP renunciaron a sus bancas en desacuerdo con el proyecto de ley, tras lo cual fueron echados del Movimiento Nacional Justicialista por su Consejo Superior.

Terragno reflexionaba en febrero de 1974 sobre este viraje que Perón hacía cada vez más evidente, al destacar cómo había variado su táctica entre enero de 1973 y enero de 1974: hacía un año su discurso estaba en línea con las expectativas juveniles y ahora el líder los enfrentaba recostándose en el aparato sindical, tratándolos de "infiltrados" y avalando la "depuración" interna. ${ }^{50}$ Desde su punto de vista, era esencial entender que Perón no era un ideólogo sino un conductor, que sus actos estaban guiados por cuestiones "tácticas", no doctrinarias, y que por ende no era un "purista" que se preocupara por la "congruencia intelectual”. Pero, aun teniendo en cuenta ello, el director advertía que lo difícil era "delimitar las astucias tácticas" sin que éstas traicionaran las "finalidades estratégicas", porque Perón estaba sometido a varias "influencias" que conspiraban contra la visión estratégica que había esbozado hacía un año; Terragno mencionaba explícitamente las influencias de los "dirigentes sindicales", el "establishment" y sus propios "colaboradores". ${ }^{51}$ Por eso, Perón no era el responsable exclusivo y principal del giro que estaba tomando su política en relación con esos "objetivos estratégicos", sino que parecía condicionado por estas "influencias" que él había avizorado pero que no podía "evitar". ${ }^{2}$ 
Lo cierto es que para la revista el enfrentamiento de la juventud peronista con Perón estaba poniendo a este sector "entre la espada y la pared". ${ }^{33}$ En marzo, el giro de Perón volvía a ser explicado en Cuestionario por motivos pragmáticos. Si en el exilio de Puerta de Hierro Perón "palmeaba en la espalda a todo el mundo", en el gobierno la prioridad era el orden y por eso necesitaba desmovilizar a ese "ejército de jóvenes" que había sido útil para luchar contra la dictadura. Sin embargo, planteaba que Perón "debería comprender mejor la desilusión de algunos jóvenes”, cuando en los años de lucha el líder les hablaba del “'socialismo nacional'” y ahora le declaraba la "guerra a las izquierdas". Ante la disyuntiva que tenía la juventud, que quería de todas maneras dar la pelea dentro del movimiento, lo que planteaba Cuestionario era que la disputa interna se resolviera a través del "voto libre", el "mandato popular" y la "democratización", al igual que la Argentina lo había hecho para superar la encerrona política a la que la había llevado la Revolución Argentina. Una vez tomado este camino, "ahí sí: quien no esté de acuerdo, no tiene más remedio que irse". ${ }^{4}$ Pero hasta el momento Perón había elegido otro camino, el "castrense", imponiendo de "arriba hacia abajo", tal vez presumiendo que una vía democratizadora beneficiaria a los que denominaba como "infiltrados". Por lo pronto, el enfrentamiento interno se había tornado "peligroso" y se imponía "detenerlo". Se estaba llegando al "borde de un abismo" y por eso advertía en estilo admonitorio 55 : "Quizás, para Perón, llegar a ese borde era un riesgo calculado: tal vez haya previsto sofrenar al caballo de la volencia [sic], justo antes de que desbarrancara. Si así fue, éste es el momento". ${ }^{6}$

Esta preocupación sobre los graves riesgos que conllevaba el crecimiento de la violencia política fue otro de los ejes editoriales de la revista. Su advertencia era política y ética. Como lo había hecho en octubre de 1973 frente al asesinato de Rucci, en abril de 1974 Terragno alertaba sobre la inutilidad de la violencia como "método" para "modificar la realidad". El crimen político, aunque se presentaba como un "modo de hacer justicia", era una metodología que en última instancia abría un proceso que iba "enfermando a la sociedad toda", su lógica imponía el "miedo" y la "deshumanización de la política”, la sociedad se iba "anarquizando" y se imponía la razón del que estaba "mejor armado”. En términos políticos, con esa "ley de la selva” eran siempre los "revolucionarios" los que perdían y el ganador era el "león” de cada sistema, el que tenía el "aparato más poderoso" o el "represor" que usaba discrecionalmente el poder estatal. Para lograr la "pacificación”, el gobierno tenía que dejar de inducir actos de violencia -como la tolerancia con la sedición policial que había depuesto al gobernador Ricardo Obregón Cano en Córdoba o la pasividad para esclarecer lo ocurrido en Ezeiza-, y quienes aspiraban al "cambio" revolucionario, principalmente la juventud, debían apelar al "trabajo político, más que al militar". ${ }^{57}$ Porque lo que le hacía falta a todo el que se planteaba "cambiar el orden social” era plasmar una "política de masas", ya que sólo esa masa "consciente y cohesionada" era capaz de enfrentar a los "intereses conservatistas" que querían mantener el "orden establecido". ${ }^{8}$

\section{El acto del 1 De mayo y la muerte de Perón: “¿Y ahora qué?”}

El escenario de cuasi ruptura de Perón con la Juventud peronista que significó el acto del $1^{\circ}$ de mayo de 1974 en la Plaza de Mayo, evidentemente tomó a Guestionario con su edición ya preparada -salió el jueves 2 de mayo-, aunque llegó a incluir un cintillo en tapa y una nota de una página en referencia al acontecimiento. En el acto, la Tendencia y Montoneros desafiaron a Perón con el recordado "¿Qué pasa, qué pasa, qué pasa, General / 'Tá lleno de gorilas el gobierno popular” y silbaron a Isabel Perón, entre otras interpelaciones. Un Perón desencajado los llamó "imberbes" y "estúpidos", habló de "infiltrados" y "mercenarios" y defendió a las organizaciones sindicales (Perón, 1974b, pp. 192-193). Ante el abierto desaire, Montoneros se retiró de la Plaza y la dejó semivacía.

Frente a los acontecimientos, Cuestionario ensayaba un equilibrio entre el realismo político y la crítica hacia la actitud de Perón. ${ }^{59}$ En principio, la conducta presidencial era hasta cierto punto "explicable" porque la juventud peronista era una "fuerza inorgánica" que se caracterizaba por una "comprensible inmadurez" y 
estaba "cerrada a la inteligencia de las necesidades tácticas ante las cuales debe inclinarse todo conductor". Por ello, por más méritos que tuviera, Perón no podía apoyarse únicamente sobre la juventud, ya que era "carente de una política de alianzas, aferrada a esquemas demasiado rígidos y caracterizados por la impaciencia”. Pero tampoco podía prescindir de ella, y como su tarea como conductor era la de realizar la síntesis necesaria, Cuestionario entendía que el discurso del $1^{\circ}$ de mayo no había encontrado en Perón esa "deseada actitud de conciliar fuerzas" que lo caracterizaba; en cambio, se había visto embargado por la crispación de la interpelación juvenil, que lo había hecho llegar al insulto y a promesas peligrosas (como cuando había dicho que los dirigentes sindicales habían visto "caer a sus dirigentes asesinados, sin que todavía haya tronado el escarmiento" o por la referencia a la lucha que se iría a iniciar si 'los malvados no cejan'). Cuestionario anhelaba que la lucha se orientara no hacía 'los imberbes', sino hacia las "fuerzas externas e internas" que habían marginado a las "mayorías del poder” y que hacían más daño que los cánticos que habían molestado al presidente. Y que antes de "tronar el escarmiento" lo que se debía forjar era ese "pueblo (...) sin divisiones inútiles"” (al que Perón también había aludido en su discurso). Tanto el peronismo como el país necesitaban de la juventud. De allí que Perón no tendría que haber sonreído cuando una larga columna de jóvenes se había retirado de la plaza: "nunca es bueno que los jóvenes se vayan, aunque no tengan razón”, concluía. ${ }^{60}$

El impacto que supuso la muerte de Perón el $1^{\circ}$ de julio de 1974 centró la mirada de Cuestionario en la incertidumbre sobre el futuro inmediato. ${ }^{61}$ El titular de tapa, “y ahora ¿QUE? (SIC)” (simulando las habituales pintadas callejeras de la época) (Figura 2), resumía el sentir de la revista, y seguramente de la sociedad en general, frente a la nueva coyuntura. En principio, era evidente que con la muerte de Perón se abría una "etapa nueva, con características propias", 62 y la revista hacía saber sus "dudas" sobre el rol que tendría el novel gobierno de Isabel Perón frente a los variados conflictos abiertos. Pero, paradójicamente, el temor a una nueva quiebra del orden institucional la había beneficiado y todos los sectores habían ofrecido un "inmediato acatamiento" a su figura. Aunque no fuera la persona "ideal", era la "elegida por el pueblo, como figura accesoria a la de Perón, pero elegida, y legalmente investida”. Sobre esa base, Cuestionario vislumbraba cuatro alternativas político-institucionales: 1) el gobierno de Isabel Perón; 2) su renuncia y la realización de nuevas elecciones; 3 ) la derogación de la Ley de Acefalía y el nombramiento de un funcionario público que completase el mandato presidencial y 4) un gobierno militar. Para Cuestionario, el gobierno de Isabel era la alternativa "preferible" frente a las restantes, sin perder de vista que debía "responder a las expectativas de la gente", por ejemplo, encarando "correcciones y ajustes" en la política económica. Desde ya, Isabel no contaría con la "paciencia" popular que se le tenía a Perón, y debía ser muy cuidadosa además en la elección de sus colaboradores, ya que con Perón éstos tenían un rol secundario que ahora cambiaría. Con estilo admonitorio, advertía que a lo que no podría aspirar (ni ella ni nadie) era a manejar "a voluntad el peronismo": ese era un "objetivo inalcanzable" para una sola persona. Por eso, también planteaba que sería "prudente" que mantuviera su gobierno al margen de las disputas internas. Si llegaba a completar el período presidencial, habría cumplido una "misión importante" y su gestión sería plausible si aseguraba la libertad al pueblo para debatir su futuro y facilitar el avance de la clase trabajadora. Si bien nada autorizaba a "descreer" de esa posibilidad, se enfrentaría a "inconvenientes serios": su inexperiencia, la "injerencia" que pudieran ejercer sobre ella allegados carentes de "desinterés y visión política" (otra referencia implícita a López Rega), la influencia que intentarían acrecentar las Fuerzas Armadas, los problemas del peronismo y la violencia que podía multiplicarse por este conflicto interno. Es que sobre el futuro del peronismo recaían las mayores dudas: ¿cuál sería su propuesta para el futuro? Para Cuestionario, tenía que darse el debate que se había postergado "peligrosamente" en vida de Perón, y por el cual se había bregado desde sus páginas, para así saber si el peronismo perduraba, si se desintegraba en beneficio de los sectores antipopulares o si lograba forjar el "germen de un nuevo gran movimiento popular". ${ }^{3}$ 
FIGURA 2

Cuestionario expresa la incertidumbre ante el fallecimiento de Perón (julio de 1974)

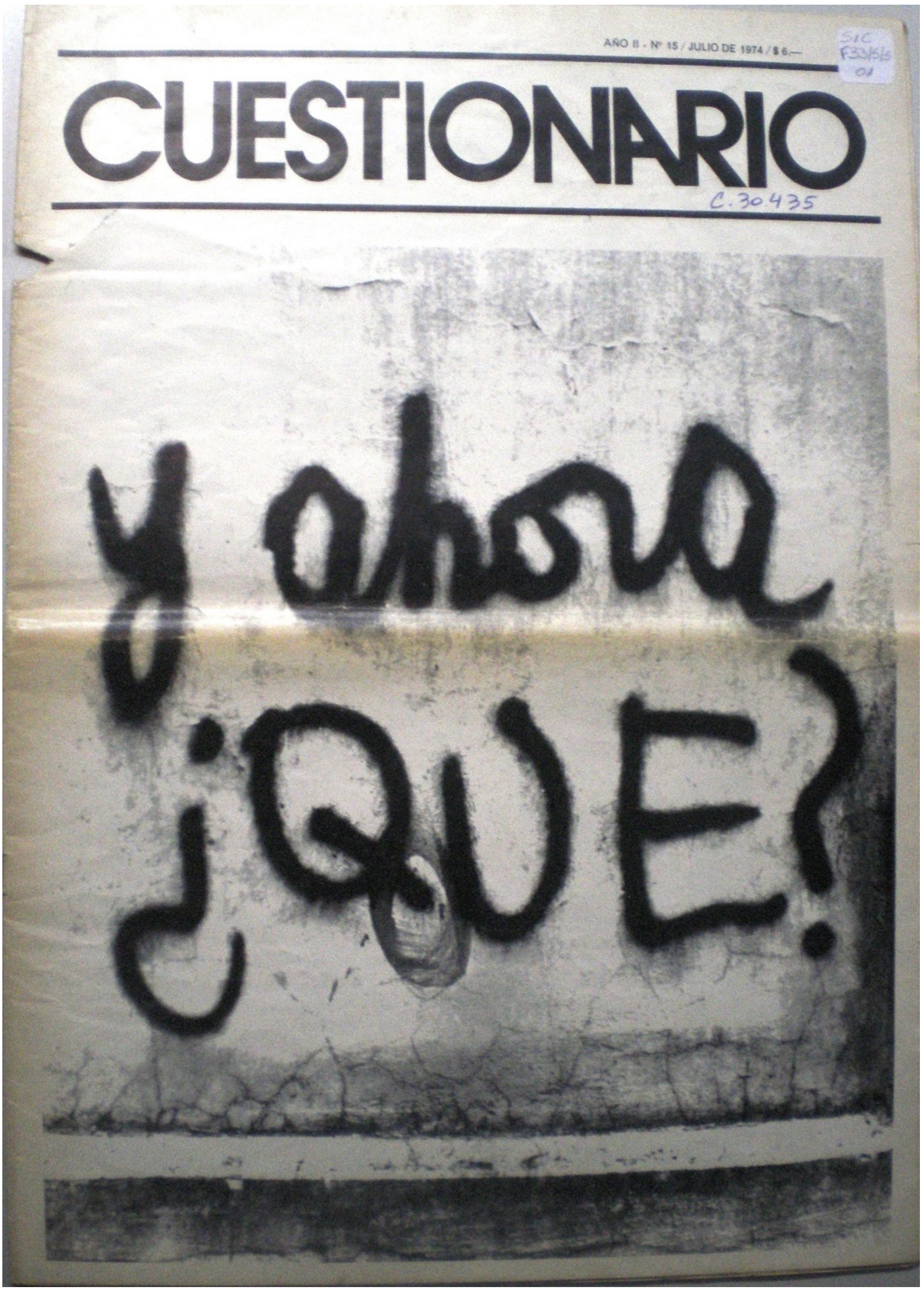


La contratapa de Terragno complementaba el análisis de la nota central. Anclada en la sensación de vacío o falta que había dejado la muerte de Perón, se titulaba: "Sin Perón". ${ }^{64}$ Por supuesto, reconocía su figura insustituible para la política argentina al destacar que estaba unido al pueblo argentino por una "devoción” y una "fe" de carácter "dogmática”. En esa amalgama política Perón no "perdía nunca”, porque los "sentimientos", cuando coincidían con intereses objetivos, generaban "fuerzas incontenibles". Con un dejo de forzada esperanza en el futuro, Terragno planteaba que inclusive su ausencia podía representar un signo de maduración para el país y el peronismo si se sabía dar buen cauce a los desafíos que se abrían:

La muerte de Perón (...) tiene el sentido favorable de obligar al país y al peronismo a moverse sin tutela, a pensar y decidir, en función de ideas e intereses, ahora que no podrán abandonarse al cómodo ejercicio de dejar que un hombre decida por ellos. Prevenirse contra el usufructo de su fantasma y contribuir con autonomía a la construcción del futuro que él propuso, son las tareas más importantes que tienen por delante los argentinos que hoy lamentan la pérdida de un caudillo impar. ${ }^{65}$

\section{Conclusiones}

La apuesta de Guestionario en esta etapa fue realizar un análisis desapasionado de la realidad política, enarbolando para ello su independencia de criterio en el ejercicio periodístico, junto con ciertos planteos programáticos para que no se perdiera el impulso reformista e igualitario con el que el peronismo había retornado al poder en 1973, y el cual había apoyado desde su óptica de izquierda moderada. En su análisis de la realidad política, observó el giro de Perón hacia la derecha de su movimiento como una jugada táctica en su rol de equilibrista que no buscaba la exclusión definitiva del ala revolucionaria, alertó sobre la gravedad de la violencia política y su repercusión negativa para los proyectos de transformación social, y planteó la pregunta "tabú" en torno al eventual fallecimiento de Perón y la irresponsabilidad de los actores políticos que no asumían la situación. Su apuesta programática fue la de la "democratización” de los diversos órganos representativos de la política y de los resortes de la economía (sin plantear un cambio de sistema), y que el peronismo realizara una "actualización doctrinaria" que debía retomar los objetivos de su sector más "evolucionado", el juvenil, pero adaptado a las condiciones que imponía la realidad de un movimiento con sectores ideológicamente contrapuestos (lo cual, por su dificultad, debía hacerse en vida de Perón). Sin duda que el "problema" para este planteo era si existía un actor o sujeto político concreto que pudiera implementar un programa de este tipo. En el marco de las luchas políticas facciosas e irreductibles de la época trazadas bajo la lógica amigo-enemigo, con un cuadro de crecimiento de la violencia política como forma de dirimir las disputas, bajo una "derechización" general del escenario político impulsada por el mismoPerón que azotaba cualquier impulso reformista desde la izquierda, la idea de "democratización”, ya de por sí ajena a los términos de la época, parecía cabalgar sobre un vacío político.

Por último, si pensamos en la posición enunciativa construida por la revista, ofreció un claro esfuerzo por tejer un discurso moderado e intelectual, con ciertas huellas del discurso académico, explicitando sí una posición política -como correspondía a una época de alta politización-, pero sin ofrecer puntos de vistas cerrados o sectarios. Su aspecto distintivo fue, entonces, el análisis razonado y no dogmático de la realidad política, enfocado en el estudio de las causas y los efectos de las decisiones de los principales actores políticos. En ese sentido, sus formas reflexivas y moderadas parecieron erigirse como un espacio de preservación frente a la desmesura, el apasionamiento y cierto carácter irracional que caracterizaron las prácticas políticas de la época.

\section{REFERENCIAS}

Baschetti, R. (Comp.) (1999). Documentos 1973-1976. Volumen II. De la ruptura al golpe. La Plata: de la Campana. Beraza, L. F. (2007). José Ignacio Rucci. Buenos Aires: Vergara. 
Bonasso, M. (1997). El presidente que no fue. Los archivos ocultos del peronismo. Buenos Aires: Planeta.

Borrat, H. (1989). El periódico, actor politico. Barcelona: Gili.

Bufano, S. y Teixido, L. (2015). Perón y la Triple A. Las 20 advertencias a Montoneros. Buenos Aires: Sudamericana.

Carman, F. (2015). El poder de la palabra escrita: revistas y periódicos argentinos: 1955-1976. Buenos Aires: Biblioteca Nacional.

Castelli, E. (1991). Manual de periodismo. Buenos Aires: Plus Ultra.

Csipka, J. P. (2013). Los 49 dias de Cámpora. Crónica de una primavera rota. Buenos Aires: Sudamericana.

De Riz, L. (1986). Retorno y derrumbe. El último gobierno peronista. Buenos Aires: Hyspamérica.

de Sagastizábal, L. y Guiliani, A. (2014). Un editor argentino. Arturo Peña Lillo. Buenos Aires: Eudeba.

Franco, M. (2012). Un enemigo para la nación: orden interno, violenciay "subversión”, 1973-1976. Buenos Aires: Fondo de Cultura Económica.

Garategaray, M. (2009). El León Herbívoro. Notas sobre la última presidencia de Perón. En XII Jornadas Interescuelas. Departamentos de Historia, San Carlos de Bariloche, Argentina: Universidad Nacional del Comahue.

Getino, O. (1995). Las industrias culturales en la Argentina. Dimensión económica y politicas públicas. Buenos Aires: Colihue.

Godio, J. (1986). Perón. Regreso, soledad y muerte (1973-1974). Buenos Aires: Hyspamérica.

Graham-Yooll, A. (2006). Tiempo de tragedias y esperanzas. Cronología histórica 1955-2005. De Perón a Kirchner. Buenos Aires: Lumiere.

Halperín, J. (2007). Noticias del poder. Buenas y malas artes del periodismo politico. Buenos Aires: Aguilar.

Kornblit, A. L. (2004). Introducción. En A. L. Kornblit (Coord.), Metodologías cualitativas en ciencias sociales (pp. 9-13.). Buenos Aires: Biblos.

Landi, O. (1978). La tercera presidencia de Perón: gobierno de emergencia y crisis politica. Buenos Aires: Cedes/Clacso.

Larraquy, M. (2004). López Rega. Buenos Aires: Sudamericana.

Maceyra, H. (1983). Cámpora/Perón/Isabel. Buenos Aires: CEAL.

Nahmías, G. (2013). La batalla peronista. De la unidad imposible a la violencia politica (Argentina 1969-1973). Buenos Aires: Edhasa.

Perón, J. (1974a). Juan D. Perón 1973-1974. Sus discursos, mensajes y conferencias completos. Volumen I. Buenos Aires: Editorial de la Reconstrucción.

Perón, J. (1974b).Juan D. Perón 1973-1974. Sus discursos, mensajes y conferencias completos. Volumen II. Buenos Aires: Editorial de la Reconstrucción.

Reato, C. (2017). Operación Traviata: ¿quién mató a Rucci? La verdadera historia. Buenos Aires: Sudamericana.

Sáenz Quesada, M. (2003). Isabel Perón. La Argentina en los años de Maria Estela Martínez. Buenos Aires: Planeta.

Seoane, M. (2003). El burgués maldito. Los secretos de Gelbard, el último líder del capitalismo nacional. Buenos Aires: Sudamericana.

Servetto, A. (2010). 73/76: el gobierno peronista contra las "provincias montoneras". Buenos Aires: Siglo XXI.

Sidicaro, R. (1993). La política mirada desde arriba. Las ideas del diario La Nación, 1909-1989. Buenos Aires: Sudamericana.

Sigal, S. y Vero\#n, E. (1985). Pero\#n o muerte: los fundamentos discursivos del feno\#meno peronista. Buenos Aires: EUDEBA.

Tcach, C. (2002). Heterodoxo diccionario de consignas orales. En C. Tcach (Comp.), La politica en consignas. Memoria de los setenta (pp. 13-78). Rosario: Homo Sapiens.

Terragno, R. (2005). Elperonismo de los 70 (I). De Cámpora a Isabelita. Buenos Aires: Capital Intelectual.

Torre, J. C. (2004). El gigante invertebrado. Los sindicatos en el gobierno, Argentina 1973-1976. Buenos Aires: Siglo XXI.

Ulanovsky, C. (2005). Paren las rotativas. Diarios, revistas y periodistas. Buenos Aires: Emecé. 
Verbitsky, H. (1998). Ezeiza. Buenos Aires: Planeta.

Yofre, J. B. (2010). El escarmiento. La ofensiva de Perón contra Cámpora y los Montoneros, 1973-1974. Buenos Aires: Sudamericana.

Zecchetto, V. (2006). La danza de los signos. Nociones de semiótica general. Buenos Aires: La Crujía.

\section{Notas}

1 El autor desea agradecer los comentarios de los evaluadores que permitieron enriquecer este artículo.

2 La década del sesentay la primera parte dela del setenta en la Argentina constituyó una "edad de oro" para los medios de comunicación en general y la prensa política en particular. El mercado periodístico de estos años era amplio, diversificado y altamente competitivo, impulsado por un crecimiento económico inusitado y por el inicio de la radicalización y el aumento de la participación popular en la política. En ese contexto, entre 1958 y 1974, la Argentina alcanzó los mayores índices de producción en cuanto a títulos y a ejemplares de diarios de toda su historia (Getino, 1995).

3 Como periodista, había sido columnista de la revista Qué (1964-1965), jefe de Redacción de la revista Confirmado (1967-1968) y columnista del diario La Opinión (1972-1973). Paralelamente, había mantenido su trabajo como abogado. Luego de su experiencia en Cuestionario continuó la actividad periodística en el exilio y una vez finalizada la dictadura militar (1976-1983) inició una reconocida trayectoria política dentro de la Unión Cívica Radical, por la cual ocupó distintos cargos públicos. Entre los más destacados, fue ministro de Obras y Servicios Públicos de la Nación (1987-1989) durante la presidencia de Raúl Alfonsín, Diputado Nacional (1993-1999), jefe de Gabinete (1999-2000) del presidente Fernando de la Rúa y Senador Nacional (2001-2007). Desde 2016 hasta 2019 fue embajador argentino ante la Organización de las Naciones Unidas para la Educación, la Ciencia y la Cultura (Unesco).

4 Entrevista telefónica con el autor, 27 de marzo de 2019.

5 En referenciaa Arturo Frondizi, presidente de la Argentina entre 1958 y 1962.

6 Entrevista telefónica con el autor, 27 de marzo de 2019 y Halperín (2007, p. 163).

7 La vinculación con la ya entonces reconocida editorial perteneciente a Arturo Peña Lillo fue breve. Según Terragno, él le propuso al editor financiar la revista, lo cual hizo en sus inicios pero luego se desvinculó para concentrarse en su negocio editorial (en efecto, ya en septiembre de 1973 no aparecía mencionada en el sumario de esa edición). Peña Lillo se dedicaba a difundir el "pensamiento nacional" a través de la publicación de textos de reconocidos autores como Arturo Jauretche, Jorge Abelardo Ramos, Raúl Scalabrini Ortiz, Rodolfo Puiggrós, José María Rosa, Ernesto Palacio o Fermín Chavez (De Sagastizábal y Giuliani, 2014).

8 Cuestionario, mayo de 1973, p. 2.

9 En efecto, ya adelantaba que la coalición triunfante en las elecciones del 11 de marzo de 1973 albergaba "corrientes incompatibles" que obligarían a un intenso debate ideológico, el cual sería recogido por la revista con el afán de desplazar a los "sectores reaccionarios" que se oponían a un "cambio sustancial" y pretendían mantener la organización socioeconómica del país con "ligeras reformas”. Asimismo, declaraba su preocupación por prevenir contra las "actitudes séctareas [sic]" y el "dogmatismo de aquellos grupos mesiánicos que se consideran depositarios de la verdad revolucionaria” (Cuestionario, "Cuál es la posición política de CUESTIONARIO”, mayo de 1973, p. 2).

10 A partir de julio de 1973 Cuestionario incluyó en el sumario de sus ediciones la siguiente leyenda: "La inserción de publicidad comercial no implica vinculación con las empresas anunciantes y la revista no se siente obligada a la defensa de los intereses particulares de esas empresas".

11 Sin contradecir necesariamente esta declaración de principios, cabe resaltar que en la tapa de su primer número de mayo de 1973 aparecía tematizado de manera jerárquica el caso DELTEC-Swift, sobre el cual la editorial Peña Lillo había publicado en 1972 el libro La carne podrida. El caso Swift-Deltec (véase la promoción de éste y otros libros de la editorial en Cuestionario, junio de 1973, p. 28). A propósito, de Sagastizábal y Giuliani (2014) aseguran que la revista era utilizada por la editorial como "vehículo de promoción de su proyecto editorial" (p. 132), de lo que efectivamente daba cuenta la sección sobre libros de Cuestionario, en la que se comentaban los libros publicados por Peña Lillo.

12 Un ejemplo se observa en su sección "Prensa política" de junio de 1973 (Cuestionario, junio de 1973, p. 14), en la que publicaba opiniones de la revista Cabildo, ligada al nacionalismo católico más ortodoxo, del escritor y militante montonero Francisco "Paco" Urondo en Liberación y del intelectual de izquierda José Pablo Feinmann en Envido. También el pluralismo, o la divergencia de opiniones, fue reivindicado como una característica intrínseca de la revista cuando publicó análisis contrapuestos de Terragno y el periodista Sergio Cerón sobre la renuncia presidencial de Cámpora (aunque bajo la aclaración de que ambos adscribían a la "línea nacional y popular") (Sergio Cerón, "Perón define objetivos y enemigos comunes y convoca a la lucha por la liberación”, Cuestionario, agosto de 1973, p. 3).

13 Lógica de la cual no estuvo totalmente ajena Cuestionario, cuando retomaba la categoría de "enemigo" para señalar cuáleseran los sectores a los que debían combatir un "gobierno popular” y el peronismo (Rodolfo Terragno, "Contra el 
utopismo”, junio de 1973, contratapa; Cuestionario, “¿Qué va a pasar?”, octubre de 1973, p. 3; Rodolfo Terragno, “¿Cuál es el enemigo?”, Cuestionario, agosto de 1974, contratapa).

14 Como ejemplo, en octubre de 1974 Cuestionario publicó una carta de la Delegación de Asociaciones Israelitas Argentinas (DAIA) en protesta por la publicación de un cartoon de Amengual que criticaba al "sionismo" mencionando que los "campos de exterminio nazis" habían resultado "meros campos de entrenamiento" comparados con la situación del pueblo palestino (Cuestionario, "La D.A.I.A da a conocer su protesta”, octubre de 1974, p. 32). La carta obligó a la respuesta de su director (Cuestionario, "Las razones de Cuestionario", octubre de 1974, pp. 32-33) y la polémica continuó en la sección "Cartas" del número de noviembre de 1974 (p. 36).

15 Comprendido como el vínculo que se establece entre el medio y el destinatario o lector, que abarca fundamentalmente dos aspectos del discurso: el reconocimiento del contenido del enunciado y la modalidad del decir de la enunciación (Zechetto, 2006, p. 274).

16 Los proyectos PICT-2016-0063 "Las revistas políticas argentinas en la encrucijada nacional: del peronismo al golpe (1973-1976)”, financiado por la Agencia Nacional de Promoción Científica y Tecnológica, y el proyecto de la Universidad de Buenos Aires UBACyT 20020170200067BA “La prensa política argentina, de Cámpora a Videla (1973-1976)", dirigidos por el autor.

17 Un frente de partidos liderado por el peronismo que se completaba con el desarrollismo y pequeños sectores desprendidos del socialismo, el radicalismo y los conservadores populares.

18 Un "frente de masas" que incluía a la Juventud Peronista (JP), el Movimiento de Villeros Peronistas (MVP), la Unión de Estudiantes Secundarios (UES), la Juventud Universitaria Peronista (JUP), la Agrupación Evita de la Rama Femenina (AE) y el Movimiento de Inquilinos Peronistas (MIP). Montoneros, la organización política-armada peronista más importante y poderosa del país, era la que definía a grandes rasgos la estrategia de las organizaciones de la Tendencia.

19 Como se ha mencionado, durante su exilio Perón había alentado a las organizaciones político-armadas peronistas y a los sectores juveniles de su movimiento como forma de lucha contra la dictadura. Eran los tiempos en los que Perón reivindicaba el "socialismo nacional”, a la "juventud maravillosa” y el "trasvasamiento generacional”, y parecía dejar en un segundo plano al sindicalismo, con el cual tenía una relación de desconfianza ya que desde allí habían surgido proyectos alternativos a su liderazgo -un peronismo "sin Perón", representado en su momento por el dirigente sindical Augusto Vandor, asesinado en 1969-. Pero luego del triunfo del 11 de marzo de 1973 comenzaría a desandar ese camino, equilibrar las fuerzas internas y mantener su figura como el gran estratega y fiel del movimiento. Para ello contó con el apoyo de un sector del sindicalismo peronista, representado por el jefe de la Confederación General del Trabajo (CGT), José Ignacio Rucci (quien de todas maneras mantuvo esa lealtad a condición de la canalización gubernamental de las demandas sindicales) (Torre, 2004).

$20 \mathrm{El}$ acuerdo fue ungido en junio de 1973 entre el Estado, los sindicatos y los empresarios, y su núcleo central era una política de ingresos concertada y que formaba parte de la estrategia de Perón para morigerar los niveles de confrontación de la sociedad. En este artículo nos hemos enfocado en el análisis político de la editorialización de Cuestionario, que fue el prioritario para la revista; de todas maneras, puede leerse su evaluación sobre los problemas que enfrentaba el Pacto Social hacia el final de la presidencia de Perón en Cuestionario, "El futuro del pacto", julio de 1974, p.6.

21 Rodolfo Terragno, "El triunfo de la realidad", Cuestionario, mayo de 1973, p. 28.

22 Ibíd.

23 De allí que en junio de 1973 se le dedicará una nota especial titulada “¿Qué es el socialismo nacional?”, en la que, justamente, se hacía hincapié en la ambigüedad del concepto y en su contenido "inespecífico" (Cuestionario, “¿Qué es el socialismo nacional?”, junio de 1973, pp. 5-6).

24 Cuestionario, "Un gabinete transitorio", junio de 1973, p. 4. La elección de Ber Gelbard, un hombre ligado al empresariado nacional (Seoane, 2003), y la adopción de la política acuerdista entre empresarios y sindicatos peronistas a través del Pacto Social, fueron evaluadas por la izquierda peronista como un claro retroceso en el camino hacia el "socialismo nacional".

25 Rodolfo Terragno, "El pueblo protagonista”, Cuestionario, julio de 1973, contratapa. Las "veinte verdades” habían sido pronunciadas por Perón desde el balcón de la Casa de Gobierno el 17 de octubre de 1950. Eran un compendio de frases breves que sintetizaban la ideología y la base filosófica del peronismo, y que distaban abiertamente de la propuesta de transformación social radical que postulaba la Tendencia Revolucionaria en 1973 (véanse en Nahmías, 2013, p. 316).

26 Rodolfo Terragno, "El futuro de Perón”, Cuestionario, agosto de 1973, contratapa.

27 En tanto diagnostica resultados de tipo social y político utilizando el método de interpretación causal determinista (Rivadaneira Prada, 1986; cit. por Castelli, 1991, pp. 195-196).

28 Rodolfo Terragno, "El futuro de Perón”, Cuestionario, agosto de 1973, contratapa.

$29 \mathrm{Al}$ momento de la asunción de Lastiri, se había enviado estratégicamente al exterior al presidente del Senado, Alejandro Díaz Bialet, a quien le hubiese correspondido asumir el cargo presidencial.

30 Aunque Cuestionario reconocía que Isabel tenía relaciones con los “peronistas reaccionarios”, entendió que su elección como candidata tenía un "sentido político" estratégico, ya que en verdad no pertenecía a ningún grupo de los que 
luchaban en la interna peronista y por su condición de esposa del líder trascendía la fragmentación partidaria. Ungirla era la forma que Perón elegía para no pronunciarse por ninguno de los sectores internos (Cuestionario, "La juventud votará a Perón", septiembre de 1973, p. 3).

31 Recuérdese que fue Isabel la que influyó en Perón durante su exilio para incorporar a López Rega a su círculo íntimo, en gran parte por sus compartidas creencias esotéricas, y ya en 1973 todos los actores políticos conocían la ambición de López Rega para quedar en una posición de poder ante la eventual muerte de Perón (Larraquy, 2004; Sáenz Quesada, 2003). Sobre López Rega, destáquese que Cuestionario anunció en su tapa de septiembre de 1973 nada menos que la publicación de sus textos esotéricos bajo el título "Así piensa López Rega". La nota mencionaba sus vínculos con la logia esotérica Anael, transcribía sus textos rayanos con el ridículo (una suerte de elegía sobre la vaca, por ejemplo) y, si bien reconocía el poder que ostentaba en ese momento, con las transcripciones de su pensamiento mostraba a un personaje grotesco (Cuestionario, “Así piensa López Rega”, septiembre de 1973, pp. 4-7). Con este antecedente, en diciembre de 1974 la revista El Caudillo de la Tercera Posición, vinculada a López Rega y a la Triple A -la banda paramilitar de derecha que el "Brujo" manejaba desde las sombras-, acusó a Terragno de "neo-marxista” por la publicación de una contratapa en Cuestionario (en una nota titulada de manera temeraria “¿Cuál enemigo?... ¿El enemigo muerto?”, en referencia, justamente, al lema de la revista dirigida por Felipe Romeo: "El mejor enemigo es el enemigo muerto”. El Caudillo de la Tercera Posición, “¿Cuál enemigo?... ¿El enemigo muerto”, 17 de diciembre de 1974, p. 7).

32 Cuestionario, “La juventud votará a Perón”, septiembre de 1973, p. 3.

33 Ibíd

34 Rodolfo Terragno, "El triunfo de la juventud", Cuestionario, septiembre de 1973, contratapa.

35 Ibíd.

36 El líder sindical era uno de los apoyos fundamentales de Perón para su política acuerdista y el asesinato fue comprendido como un intento de Montoneros de condicionar a Perón para que orientara su política hacia la senda revolucionaria. Pese a su gravedad, no implicó la ruptura entre la Tendencia y Perón, aunque profundizó la persecución hacia los sectores revolucionarios del peronismo. Terragno, en una lectura principalmente política, enfatizó la "ineficacia” del "asesinato" en tanto no modificaba la historia y, más que provocar revoluciones, eran acciones útiles a los "sectores dominantes" (y allí estaba para atestiguarlo,en su parecer,el reciente golpe de Augusto Pinochet en Chile contra Salvador Allende del 11 de septiembre de 1973). Su conclusión era categórica en la crítica hacia las organizaciones político-armadas: "Las revoluciones se hacen con movilizaciones populares. No con crímenes" (Rodolfo Terragno, "La ineficacia política del asesinato", Cuestionario, octubre de 1973, contratapa). Sobre la trayectoria de Rucci y su asesinato, véanse Beraza (2007) y Reato (2017).

37 Cuestionario, “¿Qué va a pasar?”, octubre de 1973, p. 3.

38 El $1^{\circ}$ de octubre de 1973, durante una reunión de Perón a puertas cerradas con los gobernadores peronistas en la Casa Rosada, el senador nacional, secretario general del Partido Justicialista y miembro del Consejo Superior Peronista Humberto Martiarena leyó una “orden reservada” dirigida a los delegados del Movimiento Nacional Justicialista en las provincias. Allí se promovía la "guerra contra los grupos marxistas” dentro del peronismo y se exigía que se impidiera por todos los "medios de lucha" la participación de los "marxistas infiltrados" en las actividades del peronismo, que todo peronista debía "definirse públicamente contra el marxismo, y luchar contra él” y que antes de la asunción de Perón los gobiernos provinciales debían "prescindir" de funcionarios "vinculados con el marxismo". El texto fue filtrado a la prensa y publicado el 2 de octubre por los diarios La Opinión y Crónica, y generóvariadas repercusiones. El 12 de octubre por la noche, luego de la asunción presidencial de Perón ese día (no casualmente vestido con uniforme militar), la orden fue hecha pública oficialmente por parte del Consejo Superior Peronista. Cuestionario, como Perón sabía que la paz no se lograba "con estos métodos", entendía que había sido pergeñada probablemente para calmar al sector obrero luego del asesinato de Rucci. Por ende, no tenía la intención de expulsar a la JP, sino de que "arríe sus banderas” por un tiempo para así controlar la maquinaria justicialista. Igualmente, la revista considerabala orden un "hecho desafortunado" que sería capaz de alimentar la "temible violencia", y cuestionaba particularmente la frase sobre que se apelaría a "todos los medios” para la lucha (frente a la cual se indagaba: “¿Qué quiere decir...? ¿También las armas?”; Cuestionario, “¿Qué va a pasar?”, octubre de 1973, p. 3). En marzo de 1974 su rechazo era aún más contundente al advertir sobre la "peligrosidad" del sistema persecutorio creado, además de que no contribuía a la "pacificación del peronismo" (Cuestionario, "Juventud peronista: entre la espada y la pared”, marzo de 1974, p. 6).Sobre la orden reservada, véanse Bufano y Teixido (2015, pp. 145-152); Franco (2012, p. 51); Godio (1986, p. 241); Terragno (2005, pp. 57-58); Yofre (2010, pp. 151-152). El texto completo, en Baschetti (1999, pp. 66-69).

39 El 2 de octubre de ese año Perón concurrió a la CGT y se produjo el "reencuentro" con los dirigentes sindicales. Allí el presidente electo afirmó que el movimiento sindical era "la columna vertebral del peronismo" y exhortó a combatir la "infiltración marxista" (Torre, 2004, p. 53).

40 Cuestionario, “¿Qué va a pasar?”, octubre de 1973, p. 7.

41 Rodolfo Terragno, "El pleito peronista", Cuestionario, noviembre de 1973, contratapa. 
42 Para Terragno, la democratización política se había alcanzado parcialmente con la construcción del FREJULI, pero aparecía amenazada por la intolerancia dentro del peronismo. La democratización económica suponía la "estatización" de ciertas áreas de la economía y la "desconcentración” de las restantes a través de la "cogestión” y "coparticipación”, lo cual de momento estaba postergado por la etapa "libre empresista” por la que había optado el peronismo. En el plano sindical, la democratización suponía la eliminación por las urnas de los dirigentes no representativos.

43 Rodolfo Terragno, "Una falsa alternativa”, Cuestionario, marzo de 1974, contratapa.

44 Rodolfo Terragno, "Cuando Perón no esté", diciembre de 1973, contratapa.

45 Según reconocía en su edición de abril de 1974, pensar la muerte de Perón era "tabú" porque era visto como "gorila”, ya que sus enemigos venían esperándola hacía tiempo (Cuestionario, “La sucesión”, abril de 1974, pp. 3-5).

46 Rodolfo Terragno, “Cuando Perón no esté”, Cuestionario, diciembre de 1973, contratapa.

47 Perón, el 30 de noviembre de 1973, había sugerido la necesidad de una reforma constitucional para garantizar ciertos derechos sociales (Perón, 1974a, p. 279).

48 Esta intención ya había sido esbozada en los meses posteriores al retorno peronista al poder en mayo de 1973 a través de la idea, ahora desechada, de formar una suerte de "Consejo de Estado", que sería una institución en la queestarían representadas las bases y las elites del poder, las Fuerzas Armadas, los sindicatos, los empresarios, el justicialismo y el radicalismo. De este modo, frente a la muerte de Perón, se contaría con una institución que asegurarala estabilidad del gobierno]. La idea estaba vinculada a la de "democracia integrada" que Perón entendía debía plasmarse en este retorno peronista y significaba que, además de los partidos políticos como legítimos actores de la democracia liberal, las corporaciones más relevantes debían participar institucionalmente de la función de gobierno, otorgándole así un equilibrio adicional al sistema republicano al incluirle este aspecto corporativo. Este pacto en el plano político iba de la mano del Pacto Social en el plano económico (De Riz, 1986, pp. 89, 102-103 y 111; Landi, 1978, p. 22; Maceyra, 1983, p. 55).

49 Es probable que la acción de Azul haya sido un punto de inflexión en cierta tolerancia de Perón hacia la violencia guerrillera. A corto plazo, se inició un nuevo clima político en el cuallos discursos de amplios sectores de la sociedad civil se mancomunaron para denunciar a la "subversión" (Franco, 2012, p. 75), bajo una radicalidad discursiva expresada por el propio Perón, quien poco después del asalto, por cadena nacional y vestido de uniforme militar, afirmó que había que "aniquilar cuanto antes este terrorismo criminal" (Franco, 2012, p. 70). También repercutió en la "depuración" interna del peronismo y Oscar Bidegain, el gobernador de la provincia de Buenos Aires cercano a la Tendencia, fue presionado para renunciar tras la acusación de Perón por la "desaprensión e incapacidad" y la "tolerancia culposa" que habían permitido el ataque (Perón, 1974b, p. 32). Sobre la "depuración” en las provincias contra los gobernadores ligados a la Tendencia, véase Servetto (2010).

50 Terragno citaba como ejemplo una entrevista a Perón publicada por el diario peronista ortodoxo Mayoría el 14 de enero de 1973. Allí había criticado a un sector del sindicalismo peronista al indicar que había "mucha burocracia", que él había visto "defeccionar" a los dirigentes sindicales y que el manejo sindical era "solamente para la defensa de los intereses profesionales, no da para más". En contrapartida, afirmaba que la juventud debía "hacerse cargo" porque se necesitaban "cerebros frescos y corazones tranquilos". La admonición de Perón estaba dirigida a un sector del sindicalismo, el representado en ese momento por el jefe de la Unión Obrera de la Construcción, Rogelio Coria, líder de las 62 organizaciones peronistas y representante de la línea "vandorista" de un "peronismo sin Perón". En contrapartida elogiaba al jefe de la CGT, Rucci, ya que éste hacía "lo que debe hacer” (Rodolfo Terragno, "Perón, de enero a enero”, Cuestionario, febrero de 1974, contratapa; véase también de Riz, 1986, pp. 65-66).

51 En este último grupo, aludía sin nombrarlo a López Rega, al mencionar que entre los que lo "endiosaban”, proyectaban "mausoleos" o se "hincan ante su presencia” estaban quienes lo hacían para "probarse las ropas que otro dejará", y cuya influencia era negativa porque eran un "aislante" que separaba al conductor de la realidad, con una referencia implícita a la "teoría del cerco" que la Tendencia y Montoneros habían esbozado luego de los hechos de Ezeiza, en la cualun Perón "cercado" por López Rega y su entorno era engañado y no tenía un acceso directo a su pueblo y a la realidad (Sigal y Verón, 1985, pp. 161-180).

52 Uno de esos "excesos tácticos" que Terragno atribuía a esas "influencias" eran los pasos dados por el gobierno en "materia legislativa”, lo que parecía una implícita referencia a la Ley de Asociaciones Profesionales sancionada por el Congreso a fines de noviembre de 1973, que consolidaba el poder de la CGT a nivel nacional (Bufano y Teixido, 2015, p. 242; Torre, 2004, p. 56); a la ley de Prescindibilidad, que permitía dar de baja sin causa a personal estatal, y, principalmente, a la reforma del Código Penal ya mencionada de enero de 1974 (Rodolfo Terragno, "Perón, de enero a enero", Cuestionario, febrero de 1974).

53 Cuestionario, “Juventud peronista: entre la espada y la pared”, marzo de 1974, p. 6.

54 Ibíd. Terragno, en su contratapa de abril de 1974, advertía que, pese a todo, los sectores juveniles -a los queconsideraba los más "evolucionados del peronismo"- debían permanecer dentro del movimiento peronista y no dejar que el mito de Perón quedara en manos de sus "sectores retardatarios". Pero también les exigía que hicieran su "autocrítica” para no alejarse de los trabajadores a quienes querían representar (como cuando, equivocadamente, calificaban a todo el 
sindicalismo sin distinciones como "burocracia", corriendo así el riesgo de alejarse de sus representados). Rodolfo Terragno, "El rumbo equivocado", Cuestionario, abril de 1974, contratapa.

55 Exhorta al cumplimiento de reglas, advierte peligros, llama al orden y a la concordia buscando un equilibrio permanente en el sistema frente a las contradicciones que alcanzan niveles de grave enfrentamiento (Rivadaneira Prada, 1986; cit. por Castelli, 1991: 195-196)

56 Cuestionario, “Juventud peronista: entre la espada y la pared”, marzo de 1974, p. 6.

57 Rodolfo Terragno, "El rumbo equivocado", Cuestionario, abril de 1974, contratapa.

58 Rodolfo Terragno, "Las lecciones de una muerte", Cuestionario, junio de 1974. Cuestionario no hacía una objeción generalizada de la violencia política, ya que entendía que había una "violencia legítima del pueblo", como la de la resistencia peronista o el Cordobazo. Pero en esos casos la muerte ajena podía ser una "consecuencia inevitable" pero nunca el "fin perseguido". En cambio, lo que estaba ocurriendo en la Argentina de 1974 -y su reflexión surgía luego del asesinato del sacerdote Carlos Mugica, ocurrido el 11 de mayo de 1974- era que la lógica de "tirarle a otro el muerto" indicaba que se había llegado a una frontera, en la cual“al que mata no le importa quién es la víctima”, el asesinato se volvía un mero "instrumento" y la violencia, una "práctica deshumanizante" (Rodolfo Terragno, "Las lecciones de una muerte”, Cuestionario, junio de 1974, contratapa). Mugica era una figura vinculada a la Tendencia, pero que había expresado fuertes disidencias con Montoneros en los últimos tiempos. Por eso, en los días posteriores a su asesinato hubo dudas sobre losresponsables del crimen (para la Justicia argentina su asesinato fue responsabilidad de la Triple A, véase https://www.infobae.com/politica/2019/05/11/a-45-anos-del-asesinato-del-padre-mugica-los-homenajes-su s-herederos-y-las-claves-de-su-muerte/).

59 Cuestionario, "El discurso del $1^{\circ}$ de mayo", mayo de 1974, p. 34.

60 Cuestionario, "El discurso del 1 de mayo", mayo de 1974, p. 34. Pese al tenor del enfrentamiento, y a la escenificación pública que significó la plaza semivacía, esto no supuso la expulsión de la JP del peronismo, e incluso Perón dioluego algunas señales discursivas para intentar recomponer la relación (Garategaray, 2009, p. 13).

61 Y ante el acontecimiento replicó, en una nota especial, la tapa de octubre de 1973 y los editoriales en los que demandaba discutir el escenario político ante un eventual fallecimiento del líder (Cuestionario, "La prédica de un año", julio de 1974, p. 5).

62 Cuestionario, "Y ahora ¿qué?", julio de 1974, p. 3.

63 Ibíd., p.4

64 Rodolfo Terragno, “Sin Perón”, julio de 1974, contratapa.

65 Ibíd. 